\title{
Field Investigations of Glyphosate in Urine of Danish Dairy Cows
}

\author{
Monika Krüger ${ }^{1}$, Wieland Schrödl ${ }^{1}$, Jürgen Neuhaus ${ }^{1}$ and Awad Ali Shehata ${ }^{1,2,3 *}$ \\ ${ }^{1}$ Institute of Bacteriology and Mycology, Veterinary Faculty, University of Leipzig, An den Tierkliniken 29, D-04103 Leipzig, Germany \\ ${ }^{2}$ Avian and Rabbit Diseases Department, Faculty of Veterinary Medicine, Minoufiya University, Egypt
}

${ }^{3}$ Albrecht Daniel Thaer-Institute of Agronomy, University Leipzig, Leipzig, Germany

\begin{abstract}
In the present study, thirty dairy cows from each of eight Danish dairy farms were investigated for excretion of glyphosate in urine. Blood serum parameters indicative of cytotoxicity as alkaline phosphatase (AP), glutamate dehydrogenase (GLDH), glutamate oxaloacetate transaminase (GOT), creatinine kinase CK), nephrotoxicity, (urea, creatine), cholesterol and the trace elements as manganese (Mn), cobalt (Co), selenium (Se), copper (Cu) and zinc $(\mathrm{Zn})$ were investigated. All cows excreted glyphosate in their urine but in varying concentrations. Increased levels of GLDH, GOT and CK in cows from all farms demonstrate a possible effect of glyphosate on liver and muscle cells. High urea levels in some farms could be due to nephrotoxicity of glyphosate. Also the unexpected very low levels of $\mathrm{Mn}$ and Co were observed in all animals which could be explained due to a strong mineral chelating effect of glyphosate. In contrast the mean levels of $\mathrm{Cu}, \mathrm{Zn}$ and Se were within the normal reference range. In conclusion, this study gives the first documentation to which extent Danish dairy cattle are exposed to Glyphosate and its impact on blood parameters.
\end{abstract}

Keywords: Glyphosate; Trace elements; Blood parameters; Dairy cattle; Urine

\section{Introduction}

Glyphosate ( $N$-(phosphonomethyl) glycine) is a highly effective herbicide that inhibits 5-enolpyruvyl shikimate 3-phosphate synthase (EPSPS), an enzyme of the shikimate pathway that is necessary to synthesize aromatic amino acids and other aromatic components in higher plants, algae, bacteria and fungi [1]. The herbicidal action is generated by chelating manganese required in the reduction of the flavin mononucleotide (FMN) co-factor of EPSPS [2]. Glyphosate is the most extensively used herbicide worldwide. The intensive use of glyphosate has led to its wide-spread contamination of different ecosystems where it influences plants, microorganisms, animals and many components of the food chain. Moreover, glyphosate and its primary metabolite aminomethylphosphonate (AMPA) have been detected in immature seed [3], harvested seeds [4] and ground water [5]. There are differing opinions about the safety of this herbicide because long-term toxicology studies have not been conducted and the EPSPS enzyme is absent in humans and animals [6]. However, inhibition of EPSPS is not the only activity of glyphosate in warm blooded animals. Other inhibited pathways are reported such as Cyp450 aromatase inhibition, genotoxic activity [7], teratogenic activity [8] and trace element chelation [9-11]. Also glyphosate could disturb the normal gut bacterial community $[12,13]$. Some in vitro investigations with glyphosate have verified its cytotoxic effects on different cells at very low, sub-agricultural concentrations [14-16]. In a long-term investigation, Seralini and coworkers [17] reported significantly higher mammary tumor rates in female rats drinking glyphosate at $1 \mathrm{ppb}$, a very low concentration. Marked and severe kidney nephropathies and liver congestion were also reported. In the present study, we investigated 30 cows at each of eight farms to evaluate relationships between regular intake of glyphosate in feed of dairy cows, as measured by excretion in urine, and changes in serum biochemistry, especially enzymes indicative of cytotoxicity such as alkaline phosphatase (AP), creatinine kinase (CK), glutamate dehydrogenase (GLDH), glutamate oxaloacetate transaminase (GOT); parameters demonstrating nephrotoxicity (urea, creatinine); a lipid pathway parameter (cholesterole); as well as the trace elements copper $(\mathrm{Cu})$, cobalt $(\mathrm{Co})$, manganese $(\mathrm{Mn})$, selenium $(\mathrm{Se})$, and zinc $(\mathrm{Zn})$.

\section{Material and Methods}

\section{Animals}

Thirty cows (15 fresh calving, 15 high yielding cows) at each of eight Danish farms were investigated. More details are shown in Table 1. The age of these animals ranged from 4 to 7 years with an average body weight of 550-600 Kg.

\section{Glyphosate testing of urine}

Urine samples were diluted 1:20 with distilled water (aqua distillated, Braun, Germany) and tested for glyphosate by ELISA (Abraxis, USA) according to the manufacturer's instructions. Test validation was done with Gas Chromatography-Mass Spectroscopy (GC-MS) by Medizinische Labor (Bremen, Germany). The correlation coefficient between the two tests was 0.96 (Data not shown).

\begin{tabular}{|c|c|c|}
\hline Farm & Total number of cows & Average milk yields kg/cow \\
\hline W & 150 & 9.1 \\
\hline K & 180 & 10.3 \\
\hline R & 175 & 10.2 \\
\hline V & 200 & 8.6 \\
\hline S & 140 & 10.7 \\
\hline T & 180 & 11.2 \\
\hline B & 400 & 10.8 \\
\hline E & 300 & 8.8 \\
\hline
\end{tabular}

Table 1: Characterization of Danish dairy farms investigated in this study

*Corresponding author: Awad Shehata, Institute of Bacteriology and Mycology, Faculty of Veterinary Medicine, Leipzig University, Germany, Tel: +49 341973 8181; Fax: +49 341973 8199; E-mail: shehata@vetmed.uni-leipzig.de

Received July 25, 2013; Accepted August 21, 2013; Published August 23, 2013

Citation: Krüger M, SchrödI W, Neuhaus J, Shehata AA (2013) Field Investigations of Glyphosate in Urine of Danish Dairy Cows. J Environ Anal Toxicol 3: 186 doi:10.4172/2161-0525.1000186

Copyright: ( 2013 Krüger M, et al. This is an open-access article distributed under the terms of the Creative Commons Attribution License, which permits unrestricted use, distribution, and reproduction in any medium, provided the original author and source are credited. 


\section{Investigation of blood serum for selected enzymes, electrolytes, and substrates}

Blood serum parameters indicative of cytotoxicity (AP, GLDH, GOT, CK), nephrotoxicity, (urea, creatine), cholesterol and the trace elements ( $\mathrm{Mn}, \mathrm{Co}, \mathrm{Se}, \mathrm{Cu}, \mathrm{Zn}$ ) were analyzed by an accredited veterinary diagnostic laboratory (BioCheck $\mathrm{GmbH}$, Holzhausen, Germany).

\section{Statistical analysis}

The statistical program SPSS 15 (SPSS Inc. Headquarters, $233 \mathrm{~S}$. Wacker Drive, 11th floor, Chicago, Illinois 60606) was used to analyze data. The recorded parameters were tested for normal distribution by the Shapiro-Wilkinson Test. Normal distribution of the arithmetic mean and standard deviations were calculated and median and 1st and 3rd quartiles were calculated for abnormally distributed values. Significance tests were performed using Fisher's Exact Test and the Mann-Whitney U Test.

\section{Results}

\section{Glyphosate levels in urine}

All investigated cattle excreted glyphosate in their urine but in different amounts (Figure 1). Animals at farm B excreted significantly more glyphosate than cows at the other farms. Significant differences were also seen between farms $K$ and $R$ compared to farm $E(p<0.001)$.

\section{Blood serum enzymes}

The mean levels of GLDH, GOT, CK, AP, cholesterol, creatinine and urea, the urea/creatinine quotient of the eight farms and the linear functions between glyphosate and creatinine as well as between urea and glyphosate of all investigated animals are presented in Figures 2-6. The mean GLDH level of cows at farms K, R, T, B and E were above the normal reference level $\leq 30 \mathrm{U} / \mathrm{L}$ (Figure 2). There were no significant differences between the farms but there were animals with a very high GLDH level at all farms. The means of GOT levels of cows at all farms were high with significant differences observed between farm $\mathrm{T}$ and $\mathrm{B}$ as well as farms $\mathrm{T}$ and $\mathrm{K}$ relative to farm $\mathrm{W}$ (Figure 2). The mean of $\mathrm{AP}$ levels were in the reference range although cows at farm $\mathrm{B}$ had very low AP (Figure 2). Also the CK levels were not significantly different between the eight farms, but all mean levels were excessive and indicate damage of muscle cells (Figure 2).

\section{Cholesterol, creatinine and urea}

The mean levels of cholesterol in blood serum were higher than

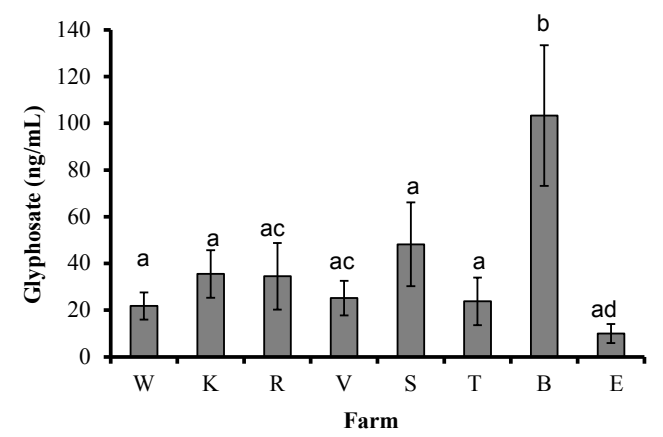

Figure 1: Glyphosate in urine of Danish cows. Significant glyphosate differences were seen between different farms (ab: $p<0.001, c d: p<0.001)$ using t-test. the postulated reference level (Figure 3). Also the means of urea levels (Figure 4) at farms K, R, V, and S were above reference (level $30 \mathrm{mg} /$ $\mathrm{dL})$. Significant differences between the farms were observed $(\mathrm{p}<$ 0.001). High urea levels were correlated with the excretion of high glyphosate concentrations in urine $(\mathrm{R}=0.72)$ (Figure 4). Furthermore high creatinine in blood was correlated with low glyphosate excretion (Figure 5). Linear function was found between glyphosate in urine (ng/ $\mathrm{mL}$ ) and creatinine $(\mathrm{mg} / \mathrm{dL})$ in blood serum of cows at eight Danish farms $(R=-0.65)$. Significant differences $(p<0.001)$ of blood serum urea/creatinine ratio were seen between different farms.

\section{Trace elements}

Trace elements as Co and Mn were far below the reference level at all farms (Figure 6). Se and Cu blood serum levels of cows at all farms were within the reference range. $\mathrm{Zn}$ levels were excessive in cows at farms $K, R, S$ and B with significant differences seen between the farms.

\section{Correlation between blood serum parameters and glyphosate}

Significant correlations between the blood serum parameters and glyphosate levels in urine of all cows are shown. Glyphosate is positively correlated with $\mathrm{CK}(\mathrm{R}=0.135)$ and $\mathrm{Zn}(\mathrm{R}=0.175)$, and negatively with $\mathrm{Se}(\mathrm{R}=-0.188)$. The only high negative trace nutrient correlation was between glyphosate and $\mathrm{Co}(\mathrm{R}=-0.403)$. Positive correlations were high between GLDH and GOT $(\mathrm{R}=0.425)$, urea and GOT $(\mathrm{R}=0.314)$, urea and cholesterol $(\mathrm{R}=0.480), \mathrm{Zn}$ and $\mathrm{Co}(\mathrm{R}=0.809)$, $\mathrm{Co}$ and $\mathrm{Se}(\mathrm{R}=0.403)$, cholesterol and $\mathrm{Se}(\mathrm{R}=0.325)$; and $\mathrm{Cu}$ and $\mathrm{Zn}(\mathrm{R}=0.809)$.

\section{Discussion}

Farm animals such as high yielding dairy cows ingest concentrated feeds like soy, corn, and other grains contaminated with the herbicide glyphosate. This contamination is especially high in genetically modified crops (GMO) with resistance to glyphosate or in those crops treated pre-harvest with glyphosate to desiccate grain or kill lateemerging weeds. This is the first report of glyphosate in the urine of dairy cows chronically contaminated with glyphosate in their feed. It is amazing that more papers are not published about glyphosate excretion by farm animals since there are many papers reporting the detection of glyphosate in urine of humans, mostly of farmers using this herbicide $[18,19]$. Curwin and co-workers [19] analysed the urine of 118 children (66 farmers, 52 non-farmers) from Iowa farm and non-farm households. The estimated daily doses of glyphosate in the two groups were the same (farm children 0.013-0.34 $\mu \mathrm{g} / \mathrm{kg} / \mathrm{day}$ and non-farm children $0.037-0.33 \mu \mathrm{g} / \mathrm{kg} /$ day. A large quantity of GMO associated food is contaminated with glyphosate $[6,20]$. Appendix II of the EU Commission of Health and Consumer Protection Directorate describes the metabolism of glyphosate after ingestion. About $30 \%$ of ingested glyphosate is absorbed, distributed in the body with low residues occurring in all tissues. Generally, accumulation is below $1 \%$ after seven days [21]. All cows in our study excreted glyphosate in their urine (Figure 1). Glyphosate levels differed between the farms, but cows at farm B excreted significantly more glyphosate than those at the other farms. This farm maybe feed high glyphosate residues in their feed or the animals at this farm had less kidney damage. The means of urea levels were within the reference range. Thus, assuming a daily urine excretion in cattle of $16-50 \mathrm{~mL} / \mathrm{kg}$ body weight per day [22] and a minimal glyphosate excretion of $10.0 \mathrm{ng} / \mathrm{mL}$ at farm $\mathrm{E}$; means between 0.096 to $0.300 \mathrm{mg}$ glyphosate would be daily excreted (average body weight is $600 \mathrm{Kg}$ ). In contrast, $103.3 \mathrm{ng} / \mathrm{mL}$ glyphosate was excreted in urine by cows at farm $\mathrm{B}$. The estimated minimal and maximal glyphosate excretion levels in urine are $0.992 \mathrm{mg}$ /day and 

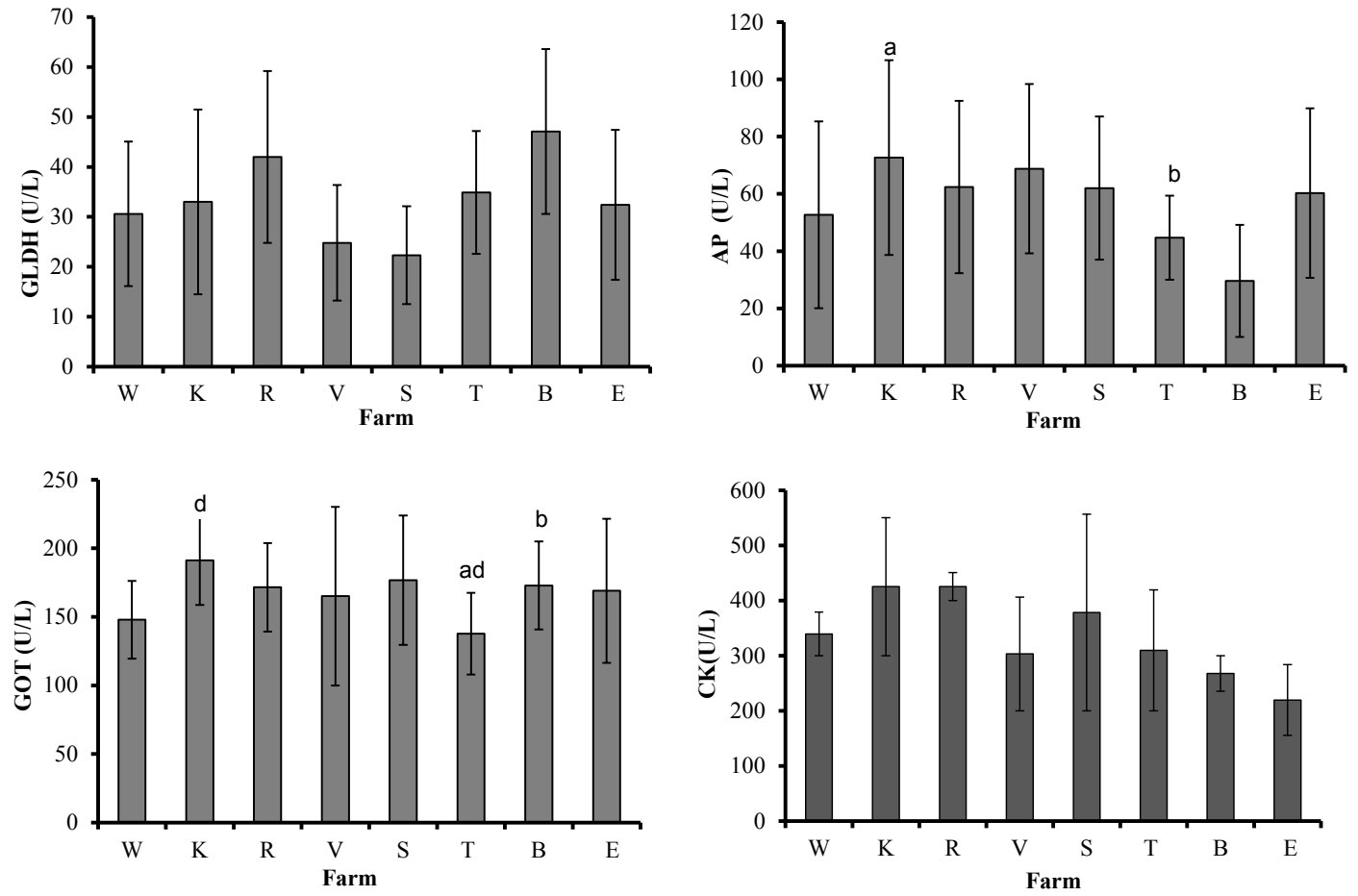

Figure 2: Enzymes levels in serum of Danish cows. The mean levels of GLDH in cows at farms $K, R, T, B$ and $E$ were above the reference level of ( $\leq 30 \mathrm{U} / \mathrm{L}$ ). Significant differences of the GOT were seen between farm $T$ and $B(a / b: p<0.001)$ and between farm $W$ and farms $K$ and $T(c / d$ : $p<0.001)$. The reference value of GOT is $<80 \mathrm{U} / \mathrm{L}$. Significant differences of AP were also seen between farm K and T ( $<<0,001)$. The reference value of GOT is $\leq 300 \mathrm{U} / \mathrm{L}$. No significant differences were seen between CK values however all values were above the postulated reference level $(\leq 100 \mathrm{U} / \mathrm{L})$.

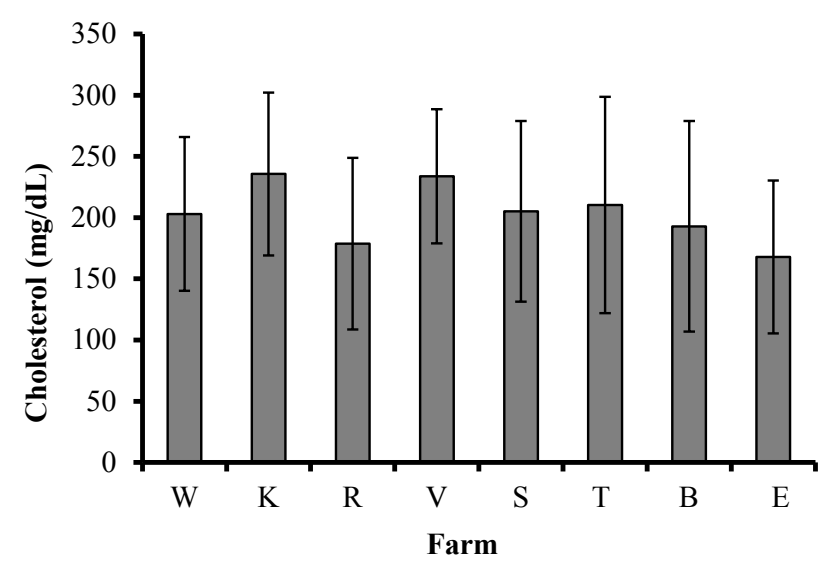

Figure 3: Cholesterol in blood serum of cows at eight Danish farms. The mean levels in all cows were higher than the postulated reference level (>75mg/L).

$3.1 \mathrm{mg} /$ day, respectively. As only about $30 \%$ of ingested glyphosate is absorbed and the other two-thirds must be excreted in feces [21] this means the expected glyphosate excretion in feces of tested cows is 2-6 mg daily. The Maximum Residue Level (MRL) for glyphosate in soy is $20 \mathrm{mg} / \mathrm{kg}$ [23]. Assuming that cows ingest two kg soy per day; they could ingest $40 \mathrm{mg}$ glyphosate per day. This indicates that the excreted glyphosate we recovered is too low, glyphosate is being metabolized in the animal to AMPA, or the level of contamination is below the MRL. In order to identify where the rest is, we can calculate that about one third of ingested glyphosate can be absorbed, distributed in the body and excreted via kidneys. An unknown amount might be metabolized and some lost during the collection and processing steps for analysis. Feeds originating from genetically modified plants (GMP) like soy or corn contain glyphosate levels permitted by the European Food Safety Authority (EFSA) that are ingested daily to possibly induce chronic diet intoxication. In our investigation the increased level of the enzymes GLDH, GOT, and CK, and the lipid profile marker cholesterol in all cows as well as high urea levels from cows at half of the farms (Figures 2-6) point to livers, kidneys and muscles damage. El-Shenawy [24] reported that rats suffering from Roundup and glyphosate damage 

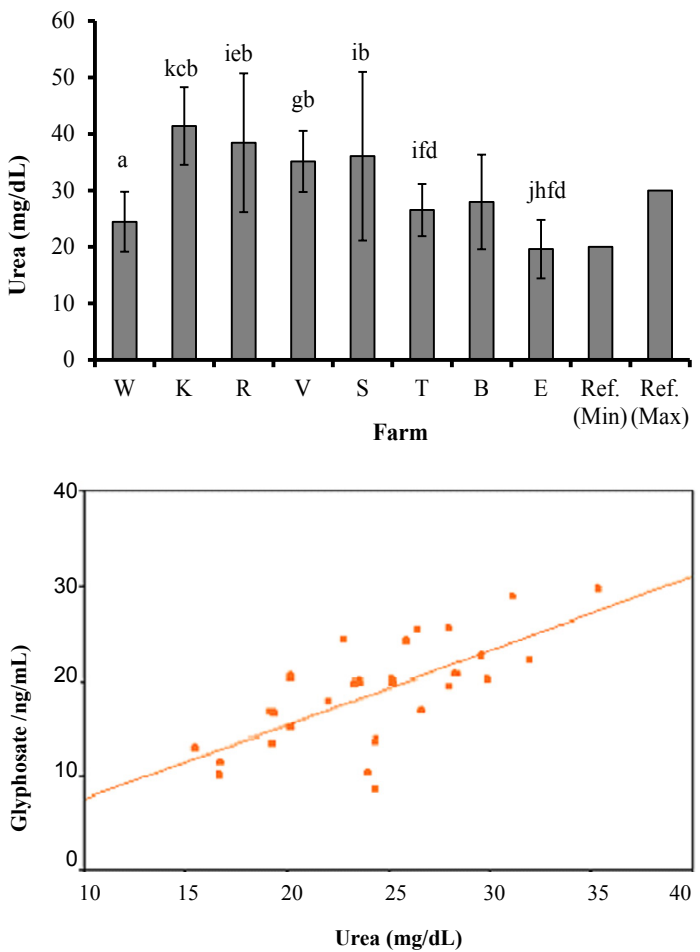

Figure 4: Urea in blood serum of Danish cows. Significant differences were seen between different farms. Ab: $p<0.001$, cd: $p<0.001$, ef: $p<0.001$, gh: $p<0.001$, ij: $\mathrm{p}<0.001$. Mean levels of farms $\mathrm{K}, \mathrm{R}, \mathrm{V}, \mathrm{S}$ were above the upper limit reference value $(20-30 \mathrm{mg} / \mathrm{dL})$. Linear function between high glyphosate in urine (ng/mL) and urea $(\mathrm{mg} / \mathrm{dL})$ in blood serum were found $(R=0.72 ; Y=0.786 x-0.355)$
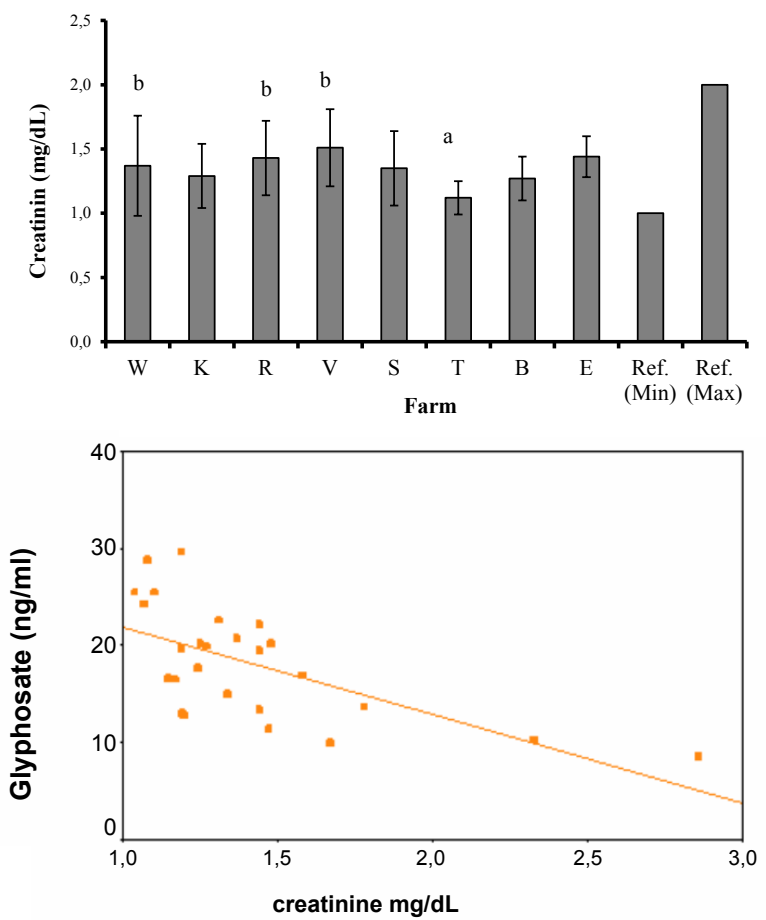

Figure 5: Creatinine in blood serum of Danish cows. Significant differences were seen between farm $T$ and farms $W, R$ and $V(a b ; p<.001)$. Linear function was found between low glyphosate in urine $(\mathrm{ng} / \mathrm{mL})$ and creatinine $(\mathrm{mg} / \mathrm{dL})$ in blood serum $(R=-0.65 ; \mathrm{Y}=-9.07 \mathrm{x}+31.06)$. 

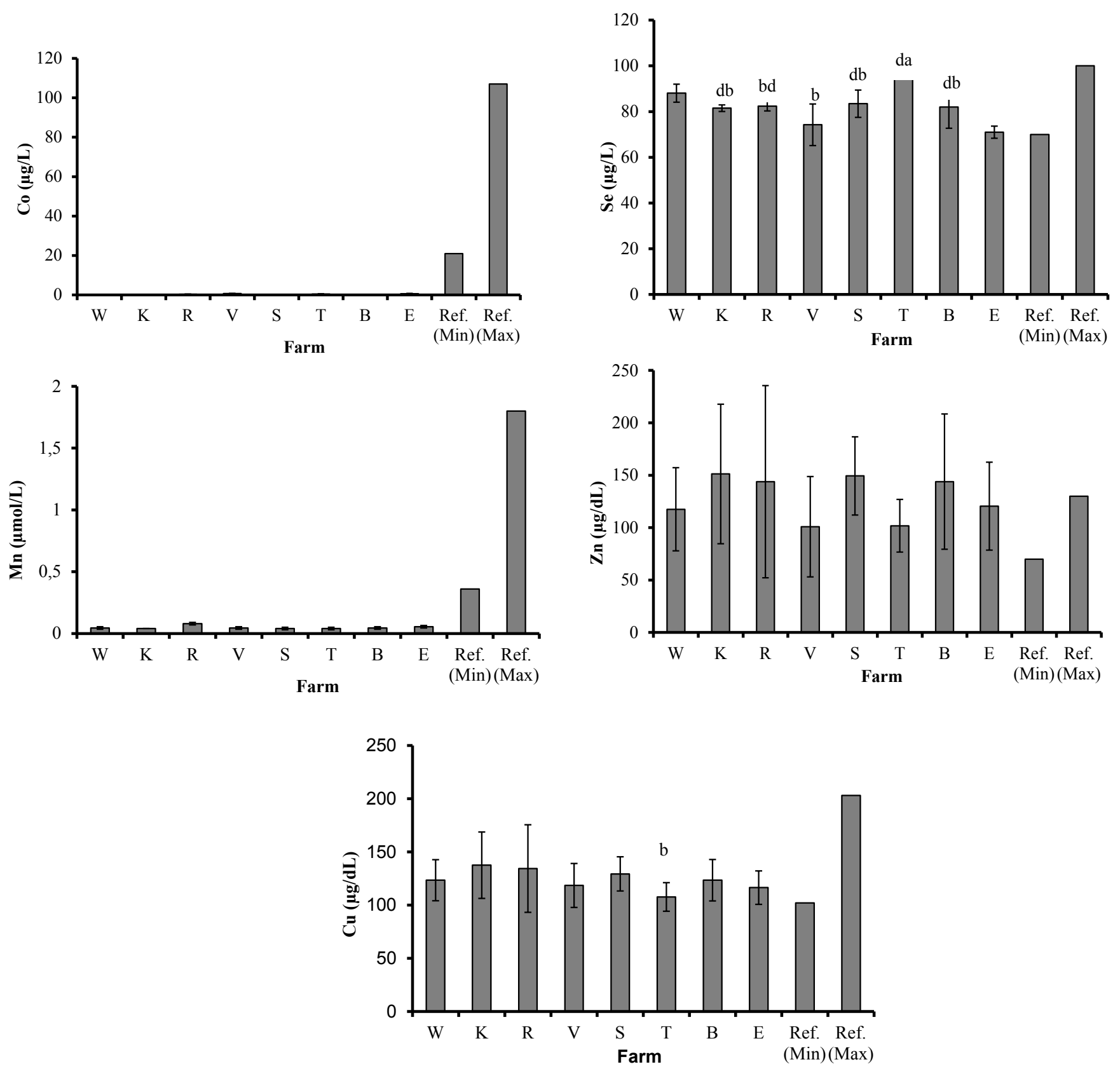

Figure 6: Trace elements in blood serum. The Co and Mn levels at all farms were far below the minimal reference level for nutrient sufficiency. Se levels in cows at all farms were within the Se reference range for nutrient sufficiency. Significant differences were seen between farm $T$ with the highest level and the other farms (ab $<0.001$ ), and farm $E$ with the lowest Se and the other farms, other than farm $V(c d: p<0.001)$. The average of $Z n$ levels in cows on farms K, R, S and B were above the maximum reference level $(150 \mu \mathrm{g} / \mathrm{dL})$. All levels of $\mathrm{Cu}$ were within the reference range for nutrient sufficiency and significant differences were seen between animals on farm $\mathrm{K}$ and $\mathrm{T}(\mathrm{ab} \mathrm{p}<0.001)$

have leakage of the hepatic intracellular enzymes ALT, GOT, and AP suggesting irreversible damage of hepatocytes starting the first week after intraperitoneal Roundup and glyphosate application. Also a significant increase of cholesterol and urea in blood serum of glyphosate or Roundup treated rats was observed. Roundup ${ }^{\circ}$ was characterized as a more probable antioxidant disruptor than the listed active ingredient itself (glyphosate). Exposure to sub-lethal concentrations of Roundup ${ }^{\star}$ promoted increased hepatic lipid peroxidation (LPO) and tumor necrosis factor alpha (TNF- $\alpha$ ) that are typical responses to stress and inflammation [25]. Similar results were reported recently $[26,27]$. Minor differences in enzyme responses of male and female rats receiving relatively large doses of Roundup were observed after 5 and 13 weeks. Similar chronic effects on enzymes were reported with small doses over 2 years. Alterations in kidney and liver function after ingestion of Roundup or GMO feed were reported $[17,27,28]$. The mean urea blood serum levels were above the reference levels of some farms. It is interesting to note that there is a positive linear relationship between urea and glyphosate excretion (Figure 4) even though the 
Citation: Krüger M, Schrödl W, Neuhaus J, Shehata AA (2013) Field Investigations of Glyphosate in Urine of Danish Dairy Cows. J Environ Anal Toxicol 3: 186. doi:10.4172/2161-0525.1000186

mean glyphosate level from cows of farm B was significantly higher than at all the other farms. Maybe the high excretion of glyphosate in urine of these cows is the result of good filtrations by kidneys. We observed a negative linear relationship between glyphosate in urine and creatinine in blood serum so that as the creatinine increased, the glyphosate in urine decreased (Figure 5). The means of creatinine levels in cows at all farms were within the reference range. The glyphosate molecule grabs on to vital nutrients so they are not physiologically available. This process is called chelation and was actually the original property for which glyphosate was patented in 1964. In 1974 it was patented as an herbicide. When applied to crops, glyphosate deprives them of vital minerals necessary for healthy plant function-especially for resisting serious soil-born diseases. This also happens after ingestion of glyphosate in the body of animals and humans. Deficiency in trace elements like $\mathrm{Mn}, \mathrm{Cu}, \mathrm{Zn}, \mathrm{Se}, \mathrm{Co}, \mathrm{B}$, and Fe as well as macro elements like $\mathrm{Mg}, \mathrm{Ca}$, and others occur. Deficiencies of these elements in diets, alone or in combination, are known to interfere with vital enzyme systems and cause disorders and diseases [29-31]. The Co and Mn levels were much too low in all animals for proper function and immune response (in comparison with reference levels). This is a result of the strong chelating effect of glyphosate especially in chelating Co and $\mathrm{Mn}$ [30-32]. Correlations between glyphosate and blood serum parameters were significant for $\mathrm{CK}(\mathrm{R}=0.135)$, Se $(\mathrm{R}=-0.188)$ and $\mathrm{Co}$ $(\mathrm{R}=-0,403)$ and $\mathrm{Zn}(\mathrm{R}=0,175)$. Correlations with the trace elements especially point to the influence of glyphosate on the health of cows.

\section{Conclusion}

All cows investigated at the eight Danish dairy farms excreted glyphosate in their urine at significant different amounts between the farms. We found increased blood serum levels of parameters indicative for cytotoxicity like GLDH, GOT, and CK and the lipid profile marker cholesterol in cows at all farms and high urea levels in half of the farm animals. Correlations between glyphosate and some of the measured blood serum parameters to $\mathrm{CK}(\mathrm{R}=0.135)$, Se $(\mathrm{R}=-$ 0.188), $\mathrm{Co}(\mathrm{R}=-0,403)$ and $\mathrm{Zn}(\mathrm{R}=0,175)$ demonstrate that glyphosate is toxic to the normal metabolism of dairy cows. This study gives the first documentation to which extent Danish dairy cattle are exposed to glyphosate and its impact on different blood parameters.

\section{References}

1. Barry G, Padgette SR (1992) Glyphosate tolerant 5-enolpyruvylshikimate-3phosphate synthases. World Patent, WO 92/04449.

2. Cerdeira AL, Duke SO (2006) The current status and environmental impacts of glyphosate-resistant crops: a review. J Environ Qual 35: 1633-1658.

3. Lorenzatti E, Maitre MI, Argelia L, Lajmanovich R, Peltzer P, Anglada M (2004) Pesticide residues in immature soybeans of Argentina croplands. Fresenius Environ Bull 13:675-678.

4. Duke SO, Baerson SR, Rimando AM (2003) Herbicides: Glyphosate. In J.R Plimmer, D.W Gammon, and N.N Ragsdale (eds.) Encyclopedia of Agrochemicals.

5. Sanchís J, Kantiani L, Llorca M, Rubio F, Ginebreda A, et al. (2012) Determination of glyphosate in groundwater samples using an ultrasensitive immunoassay and confirmation by on-line solid-phase extraction followed by liquid chromatography coupled to tandem mass spectrometry. Anal Bioanal Chem 402: 2335-2345.

6. De Roos AJ, Svec MA, Blair A, Rusiecki JA, Dosemeci M, et al. (2005) Glyphosate results revisited: De Roos et al. respond. Environ Health Perspect 113: A366-A367.

7. Poletta GL, Larriera A, Kleinsorge E, Mudry, MD (2009) Genotoxicity of the herbicide formulation Roundup (glyphosate) in broad-snouted caiman (Caiman latirostris) evidenced by the comet assay and the micronucleus test. Mutat Res 672: 95-102.
8. Paganelli A, Ganzzo V, Acosta H, López LS, Carrasco AE (2010) Glyphosatebased herbicides produce teratogenic effects on vertebrates by impairing retinoic acid signaling. Chem Res Toxicol 23: 1586-1595

9. Huber D (2007) What about glyphosate-induced manganese deficiency? Fluid J. Fall: $20-22$.

10. Zobiole LHS, de Oliviera RS, Huber DM, Constantin J, de Castro C, et al. (2009) Glyphosate reduces shoot concentration of mineral nutrients in glyphosateresistant soybeans. Plant soil 328: 57-69.

11. Zobiole LHS, Oliveira RS, Kremer RJ, Constantin J, Yamada T, et al (2010) Effect of glyphosate on symbiotic N2 fixation and nickel concentration in glyphosate-resistant soybeans. Appl Soil Ecol 44: 176-180.

12. Shehata AA, Schrödl W, Aldin AA, Hafez HM, Krüger M (2013) The effect of glyphosate on potential pathogens and beneficial members of poultry microbiota in vitro. Curr Microbiol 66: 350-358.

13. Krüger M, Shehata AA, Schrödl W, Rodloff A (2013) Glyphosate suppresses the antagonistic effect of Enterococcus spp. on Clostridium botulinum. Anaerobe 20: 74-78

14. Benachour N, Sipahutar H, Moslemi S, Gasnier C, Travert C, et al. (2007) Time- and dose-dependent effects of roundup on human embryonic and placental cells. Arch Environ Contam Toxicol 53: 126-133.

15. Benachour N, Séralini GE (2009) Glyphosate formulations induce apoptosis and necrosis in human umbilical, embryonic, and placental cells. Chem Res Toxicol 22: 97-105.

16. Gasnier C, Dumont C, Benachour N, Clair E, Chagnon MC, et al. (2009) Glyphosate based herbicides are toxic and endocrine disruptors in human cell lines. Toxicology 262:184-191.

17. Séralini GE, Clair E, Mesnage R, Gress S, Defarge N, et al. (2012) Long term toxicity of a Roundup herbicide and a Roundup-tolerant genetically modified maize. Food Chem Toxicol 50: 4221-4231.

18. Acquavella JF, Alexander BH, Mandel JS, Gustin C, Baker B, et al. (2004) Glyphosate biomonitoring for farmers and their families: results from the farm family exposure study. Environ Health Perspect 12: 321-326.

19. Curwin BD, Hein MJ, Sanderson WT, Streiley C, Heederik D, et al. (2007) Pesticide dose estimates for children of lowa farmers and non-farmers. Environ Res 105: 307-315.

20. Solomon KR, Anadón A, Carrasquilla G, Cerdeira AL, Marshall JP, et al. (2007) Coca and poppy eradication in Colombia: environmental and human health assessment of aerially applied glyphosate Rev. Environ Contam Toxicol 190: 43-125.

21. Anonymous (2001) Commission working document. Review report for the active substance glyphosate. Finalized in the Standing Committee on Plant Health at its meeting on 29 June 2001 in view of the inclusion of glyphosate in Annex I of Directive 91/414/EEC.

22. Kraft W, Dürr UM (1999) Harnapparat. Auflage, 169-200 In: W. Kraft und UM Dürr (eds.) Klinische Labordiagnostik in der Veterinärmedizin 5., Stuttgardt New York: Schattauer.

23. Anonymous (2001) Pesticide Residues in Food and Feed. FAO/WHO codex alimentarius.

24. El-Shenawy NS (2009) Oxidative stress responses of rats exposed to Roundup and its active ingredient glyphosate. Environ Toxicol Pharmacol 28: 379-385.

25. Beuret CJ, Zirulnik F, Gimenez MS (2005) Effect of the herbicide glyphosate on liver lipoperoxidation in pregnant rats and their fetuses. Reprod Toxicol 19 : 501- 504.

26. Caglar S, Kolankaya D (2008) The effect of sub-acute and sub-chronic exposure of rats to the glyphosate-based herbicide Roundup. Environ Toxicol Pharmacol 25: 57-62.

27. Séralini G, Cellier D, de Vendomois JS (2007) New analysis of a rat feeding study with genetically modified maize reveals signs of hepatorenal toxicity. Arch Environ Contam Toxicol 52: 596-602.

28. De Vendômois SJ, Roullier F, Cellier D, Seralini GE (2009) A comparison of the effects of three GM corn varieties on mammalian health. Int J Biol Sci 5 : 706-726.

29. Johal GS, Huber DM (2009) Glyphosate effects on diseases of plants. Europ J Agron 31:144-152. 
Citation: Krüger M, Schrödl W, Neuhaus J, Shehata AA (2013) Field Investigations of Glyphosate in Urine of Danish Dairy Cows. J Environ Anal Toxicol 3: 186. doi:10.4172/2161-0525.1000186

Page 7 of 7

30. Cakmak I, Yazici A, Tutus Y, Ozturk L (2009) Glyphosate reduced seed and leaf concentrations of calcium, manganese, magnesium, and iron in nonglyphosate resistant soybean. Europ J Agron 31: 114-119.

31. Eker S, Ozturk L, Yazici A, Erenoglu B, Roemheld V, et al. (2006) Foliar applied glyphosate substantially reduced uptake and transport of iron and manganese in sunflower (Helianthus annuus L.) plants. J Agric Food Chem 54: 1019-1025

32. Zobiole LHS, de Oliviera OB, Kremer RJ, Muniz AS, de Oliveira A (2010) Nutrient accumulation and photosynthesis in glyphosate-resistant soybean is reduced under glyphosate use. J Plant Nutr 33: 1860-1873. 